\title{
A meiosis-specific protein kinase homolog required for chromosome synapsis and recombination
}

\author{
Beth Rockmill and G. Shirleen Roeder \\ Department of Biology, Yale University, New Haven, Connecticut 06511-8112 USA
}

\begin{abstract}
The mek1 (meiotic kinase) mutant of Saccharomyces cerevisiae was isolated in a screen for sporulation-proficient, meiotic-lethal mutants. Diploids homozygous for a mek1 null mutation produce only $13 \%$ viable spores. mek1 spore inviability is rescued by a spo13 mutation, which causes cells to bypass the meiosis I division. In a mek1 null mutant, meiotic recombination is reduced but not completely eliminated. Nuclear spreads of meiotic chromosomes from mek1 diploids reveal numerous stretches of synaptonemal complex (SC) that are shorter than wild-type SCs. Analysis of a mek1::lacZ fusion gene and Northern blot hybridization demonstrate that the MEK1 transcript is present only in meiosis. The sequence of the MEK1 gene predicts a 56.8 -kD protein with homology to serine-threonine protein kinases. The MEK1 gene maps to chromosome XV, $13 \mathrm{cM}$ proximal to $C D C 64$. Models for the function of the MEK1 gene product are proposed.
\end{abstract}

[Key Words: Yeast; protein kinase; meiosis; synaptonemal complex; meiotic recombination]

Received August 23, 1991; revised version accepted October 4, 1991.

Vegetatively growing cells of $S$. cerevisiae can undergo two fates-mating and sporulation-that may be viewed as developmental pathways. Both disrupt normal vegetative growth and require the expression of specific sets of genes and the differentiation of specialized structures. The decision to sporulate depends on both genetic and environmental signals. To sporulate, cells must express genes at both the MATa and MAT $\alpha$ loci and be starved for nitrogen. These signals converge on a cascade of genes regulating the transcription of sporulation-specific genes (Malone 1990). During sporulation, the yeast cell undergoes meiosis, a specialized type of cell division in which two rounds of chromosome segregation follow a single round of chromosome replication. The result is four haploid nuclei encapsulated by spore walls /spores or gametes), collectively called a tetrad.

The meiotic cell division can take $>10$ times as long as mitotic division. This is because the basic cell division cycle is modified by the addition of several processes unique to meiosis. In prophase I, the most lengthy phase, homologous chromosomes undergo high levels of recombination. Concurrently, homologous chromosomes align with each other, and a meiosis-specific organelle, the synaptonemal complex (SC) (for review, see von Wettstein et al. 1984), differentiates along the length of each chromosome pair. Synapsis and recombination are followed by the reductional division in which homologous chromosomes disjoin from each other. This first division is specific to meiotic cells and precedes the meiosis II equational division, which is similar to mitosis. This elaborate pattern of cell division requires meiosis- specific gene products as well as gene products common to vegetative growth.

The SC is a tripartite proteinaceous structure consisting of two lateral elements (each representing a pair of sister chromatids) flanking a central element (von Wettstein et al. 1984). In some organisms, full-length, but unpaired, axial elements (the precursors to lateral elements) are apparent prior to SC formation. The SC is most extensive during the pachytene stage of meiosis $I$ prophase, during which homologous chromosomes are tightly synapsed along their entire length. The role of the $\mathrm{SC}$ is currently not understood; it may participate in the catalysis of recombination events, in regulating the distribution of exchanges, and/or in establishing associations between homologs that ensure their proper orientation on the meiotic spindle (Egel 1978; Maguire 1978b, 19881.

Reciprocal crossing-over results in connections between homologous chromosomes, called chiasmata (Jones 1987), which are necessary for proper reductional segregation. Chiasmata are microscopically apparent in the late stages of prophase I and at metaphase I, after the SC has dissolved, when they serve to orient bivalents at the metaphase I plate. Chiasmata hold homologs together because sister chromatids are held together distal to each chiasma by sister chromatid cohesion (Maguire 1990|. In the absence of crossing-over and chiasma formation, homologs separate from each other prematurely and are just as likely to segregate to the same pole as to opposite poles at meiosis I. Thus, nonrecombinant chromosomes frequently nondisjoin. For this reason, mu- 
tants defective in meiotic recombination or synapsis often display meiotic lethality (for reviews, see Baker et al. 1976; Hawley 1988).

In an effort to understand the relationship between synapsis and recombination and to elucidate their roles in meiotic chromosome segregation, meiotic-lethal mutants have been isolated. The mek1 mutant described here displays reduced levels of meiotic recombination and a novel phenotype with regard to chromosome synapsis. The MEK1 gene product is homologous to serinethreonine protein kinases and is produced only in meiotic cells.

\section{Results}

The mek1-1 mutant is defective early in meiosis

The mek1-1 mutant of $S$. cerevisiae was isolated in a screen for meiotic-lethal mutants as described previously (Rockmill and Roeder 1988). The original mek1-1 mutant, BR1826-3Bm4, sporulates efficiently $(63 \%)$, but only $30 \%$ of the spores produced are viable. A diploid (BR2481) heterozygous for the mek1-1 allele produces $95 \%$ viable spores, indicating that the mutation is recessive. Tetrads from this diploid displayed $2: 2$ segregation for the meiotic-lethal phenotype, demonstrating that the phenotype is caused by a mutation in a single gene (data not shown).

To assess whether the mek1-1 mutant is defective at an early stage of meiosis, a mek1-1 spo13 double mutant was constructed and analyzed. In spo13 diploids, meiotic recombination and synapsis are followed by a single round of predominantly equational chromosome segregation (Klapholz and Esposito 1980). The single round of chromosome segregation results in two-spored asci / dyads), in which both spores are diploid. Because the reductional division is bypassed, spore viability is restored to many meiotic mutants with defects in recombination (and consequently the reductional division) (Malone and Esposito 1981; Rockmill and Roeder 1988; Engebrecht and Roeder 1989; Hollingsworth and Byers 1989; Menees and Roeder 1989; Malone et al. 1991). The viability of the mek1-1 spo13 double mutant (BR2702) is $81 \%$ (compared to $67 \%$ in a congenic wild-type strain), indicating that spore viability in a mek 1 mutant is restored by a spo13 mutation. Thus, the mek1-1 mutant is probably defective in some aspect of the reductional division.

Because mek 1 spore lethality is rescued by spo13, recombination can be measured in the meiotic products of the double mutant. Intragenic recombination was measured in auxotrophic diploids carrying a pair of mutant alleles at the same locus (i.e., heteroalleles). Prototrophs usually result from gene conversion (Hurst et al. 1972). In a mek1-1 strain, BR2702, the frequencies of meiotic prototrophs at two loci were reduced to $14 \%$ and $6 \%$ of the frequencies in an isogenic MEK1 strain, BR2738 (Table 1). These results are consistent with the hypothesis that the MEK1 gene product acts at an early stage in meiosis.

\section{MEKl is a new gene on chromosome XV}

The MEK1 gene was cloned by complementation of the spore inviability phenotype. Subcloning localized the complementing activity to a $5-\mathrm{kb}$ EcoRI fragment. To further localize the $M E K 1$ gene, the $5-\mathrm{kb}$ fragment was mutagenized with a derivative of the bacterial transposon Tn3 marked with the yeast LEU2 gene (Seifert et al. 1986). Transposon mutagenesis was carried out in bacteria, and the resulting mutations were transformed into yeast (Materials and methods). Diploids homozygous for each insertion were scored for the meiotic-lethal phenotype. Insertions that mapped within a region of $\sim 2 \mathrm{~kb}$

Table 1. Meiotic gene conversion in mekl mutants

\begin{tabular}{|c|c|c|c|c|c|c|c|c|c|}
\hline & & $\operatorname{leu} 2-27^{\mathrm{a}}$ & & his $4-280^{\mathrm{a}}$ & & thr1-1 $1^{\mathrm{a}}$ & & $\operatorname{trp} 1-1^{\mathrm{a}}$ & \\
\hline Strain & $\begin{array}{l}\text { Relevant } \\
\text { genotype }\end{array}$ & $\begin{array}{l}\text { leu2-3,112 } \\
\left(\times 10^{-6}\right)\end{array}$ & $\begin{array}{l}\text { Percent of } \\
\text { wild type }\end{array}$ & $\begin{array}{l}\text { his } 4-260 \\
\left(\times 10^{-6}\right)\end{array}$ & $\begin{array}{l}\text { Percent of } \\
\text { wild type }\end{array}$ & $\begin{array}{l}\text { thr1-4 } \\
\left(\times 10^{-6}\right)\end{array}$ & $\begin{array}{l}\text { Percent of } \\
\text { wild type }\end{array}$ & $\begin{array}{l}\operatorname{trp} 1-289 \\
\left(\times 10^{-6}\right)\end{array}$ & $\begin{array}{l}\text { Percent of } \\
\text { wild type }\end{array}$ \\
\hline BR2738 & wild type & 440 & 100 & 7900 & 100 & & & & \\
\hline BR2702 & mek1-1 & 25 & 6 & 1100 & 14 & & & & \\
\hline BR2722 & $\begin{array}{l}\text { mek1-1 } \\
\text { mer1::LYS2 }\end{array}$ & 0.5 & 0 & 0.1 & 0 & & & & \\
\hline BR2739 & $\operatorname{mer} 1:: L Y S 2$ & 16 & 4 & 260 & 3 & & & & \\
\hline BR2625 & wild type & 540 & 100 & 6500 & 100 & 760 & 100 & 83 & 100 \\
\hline BR2626 & mek1:LYS2 & 24 & 4 & 950 & 15 & 9.8 & 1 & 7.2 & 9 \\
\hline BR2500 & $\operatorname{red} 1:: A D E 2$ & & & 540 & 8 & 14 & 2 & 86 & 104 \\
\hline BR2725 & $\begin{array}{l}\operatorname{mek} 1:: L Y S 2 \\
\text { red1:LEU2 }\end{array}$ & & & 1300 & 20 & 9.8 & 1 & 12 & 14 \\
\hline
\end{tabular}

Frequencies of meiotic prototroph formation in wild-type and mek1 strains homozygous for spo13 are presented. The rate of meiotic prototrophy was determined by subtracting the mitotic (premeiotic) frequency from the meiotic frequency for each experiment and averaging the meiotic values. At least four experiments were done for each strain. The first four and last four strains are isogenic. The values for BR2500 were taken from Rockmill and Roeder (1990). The median mitotic frequencies were $2.8 \times 10^{-7}, 7.5 \times 10^{-5}, 1.0 \times$ $10^{-7}$, and $9.0 \times 10^{-7}$ for LEU2, HIS4, THR1, and TRP1, respectively.

a Percent of wild type was calculated by dividing the mean meiotic frequency for the mutant by the mean meiotic frequency for the isogenic wild-type strain and multiplying by $100 \%$. 
resulted in a recessive meiotic-lethal phenotype (Fig. 1). A haploid carrying one such insertion mutation was mated to a mek1-1 haploid to test for complementation. The diploid produced inviable spores, indicating that the cloned DNA represents the wild-type allele of mek1-1.

To establish the chromosomal location of the MEK1 gene, radioactively labeled $M E K 1$ DNA was used to probe a blot of electrophoretically separated yeast chromosomes (Chu et al. 1986). A doublet band corresponding to chromosomes XV and VII was identified. The $M E K 1$ gene was then used to probe a second blot containing chromosomes from a yeast strain in which chromosome VII was fragmented as a result of translocation (P. Hieter, unpubl.) and the MEK1 probe hybridized to chromosome XV. Tetrad analysis localized the MEK1 gene to the right arm of chromosome $\mathrm{XV}, 13 \mathrm{cM}$ proximal to CDC64 (48 PD : 0 NPD : $17 \mathrm{TT}$ ) and $23 \mathrm{cM}$ proximal to RPA190 (27 PD : 1 NPD : 13 TT) [(TT) tetra type; (PD) parental ditype; (NPD) nonparental ditype.]

Ajimura and Ogawa have isolated and characterized a collection of yeast mutants defective in meiotic recombination. Based on a comparison of DNA sequences (S. Leem and $\mathrm{H}$. Ogawa, pers. comm.), we have recently determined that $M E K 1$ is the same as the gene designated $M R E 4$ by those workers.

\section{A mekl null mutation reduces but does not eliminate meiotic recombination}

Because the mek1-1 mutation only reduces spore viability to $30 \%$ and decreases, but does not eliminate, meiotic recombination, it was important to determine whether a null mutation has a more pronounced effect. A null allele of $M E K 1$ was constructed by deleting $1.5 \mathrm{~kb}$ of the sequences required for complementation and replacing them with the LYS2 gene. This construct lacks $342 \mathrm{bp}$ of upstream sequences and most of the MEK1coding region (see below). The spore viability of a diploid homozygous for the mek1::LYS2 allele (BR2736) was

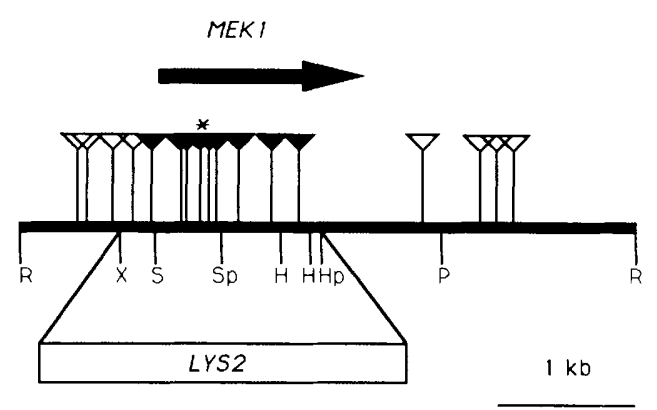

Figure 1. Restriction map of the $M E K 1$ region. $(\nabla)$ Insertion mutations that do not cause spore lethality; $(\nabla)$ insertions that cause meiotic lethality. The end points of the mek $1:: L Y S 2$ deletion-disruption mutation are indicated. The extent and orientation of the ORF is indicated by an arrow. $\left({ }^{*}\right)$ The transposon that generated an in-frame fusion with MEK1. The LYS2 gene is not drawn to scale. Abbreviations of restriction sites: (R) EcoRI; (X) XbaI; (H) HindIII; (Hp) HpaI; (P) PvuII; (S) SacI; (Sp) SpeI.
$13 \%$ compared to $>95 \%$ for related wild-type strains. As in the original mutant, the spore viability of a mek $1:: L Y S 2$ homozygote was rescued by a spo13 mutation (BR2724; Table 2).

Meiotic gene conversion was assayed at four loci in a mek1::LYS2 spo13 diploid (BR2626; Table 1). Like mek11 , the mek1 null mutation reduces, but does not eliminate, meiotic prototroph formation. Interestingly, the effect varies from locus to locus, reducing prototroph formation from $1 \%$ to $15 \%$ of wild type. Meiotic recombination in both mek1 mutants is significantly elevated over the mitotic background level.

Crossing-over was measured on chromosomes III and VIII by dissection and analysis of dyads from spo13 diploids. In the mek $1:: L Y S 2$ strain, map distances in the HIS4-MAT and ARG4-THR1 intervals are decreased to $6 \%$ and $15 \%$ of wild type, respectively (Table 2 ).

Ectopic recombination (i.e., recombination between homologous sequences on nonhomologous chromosomes) is induced almost as much as allelic recombination in meiosis (Jinks-Robertson and Petes 1985; Lichten et al. 1987). The level of ectopic recombination was measured in isogenic wild-type and mek 1 diploids, carrying a single copy of the ura3-Stu allele at the HIS4 locus on chromosome III and four copies of the ura3-1 allele (two at the URA3 locus on chromosome $\mathrm{V}$ and two at the spo13 locus on chromosome VIII). The results presented in Table 3 indicate that the frequency of $\mathrm{Ura}^{+}$ectopic recombinants in the mek 1 mutant is $42 \%$ of the wildtype level.

\section{Chromosomes in mekl mutants}

form short stretches of $S C$

To determine whether mek 1 mutants are defective in synapsis, spreads of meiotic chromosomes from wildtype and mutant strains were prepared according to the procedure of Dresser and Giroux (1988), as modified by Engebrecht and Roeder (1990). In wild type, the chromosomes are synapsed throughout their length during pachytene (Fig. 2A). Although wild-type pachytene spreads were never observed in mek1-1 or mek $1:: L Y S 2$ diploids, apparently normal but shorter stretches of SC were usually observed (Fig. 2B-E). Because the axial elements in mek1 mutants are not discrete, it is difficult to determine whether the short stretches of SC observed involve homologous chromosomes (i.e., axial elements of equivalent length). In at least some mek1 nuclei, the number of SCs observed is similar to the number of chromosomes (or twice the number of bivalents; Fig. 2E). If these are nonhomologously paired chromosomes, some of these structures could represent individual chromosomes folded back on themselves. There is extensive SC formation during meiosis in haploid yeast (Fig. 2F; Loidl et al. 1991), demonstrating that SC can assemble between nonhomologous chromosome segments. The frequency and timing of mek1 nuclei containing short SC approximates the frequency and timing of wild-type nuclei containing fully synapsed chromosomes (Fig. 3). 
Table 2. Crossing-over in the mekl mutant

\begin{tabular}{|c|c|c|c|c|c|c|c|}
\hline Strain & $\begin{array}{l}\text { Relevant } \\
\text { genotype }\end{array}$ & $\begin{array}{l}\text { Percent } \\
\text { spore viability }\end{array}$ & $\begin{array}{l}\text { Number 2- } \\
\text { spore viable }\end{array}$ & $\begin{array}{l}\text { HIS4-MAT } \\
\text { TT : NPD } \\
\text { (total) }\end{array}$ & $\begin{array}{l}\text { HIS4-MAT } \\
\text { (cM) }\end{array}$ & $\begin{array}{l}\text { ARG4-THR1 } \\
\frac{\text { TT }: \text { NPD }}{\text { (total })}\end{array}$ & $\begin{array}{l}\text { ARG4-THR1 } \\
\text { (cM) }\end{array}$ \\
\hline \multirow[t]{2}{*}{ BR2723 } & $M E K 1$ & 83 & 68 & $16: 3$ & 54 & $11: 0$ & 16 \\
\hline & & & & 63 & & 68 & \\
\hline \multirow[t]{2}{*}{ BR2724 } & mek1::LYS2 & 78 & 115 & 9:0 & 8.0 & $1: 0$ & 0.9 \\
\hline & & & & $\overline{112}$ & & $\overline{115}$ & \\
\hline
\end{tabular}

Dyads in which nondisjunction occurred were eliminated from the map distance calculation (i.e., dyads containing one mater and one nonmater). Map distances were calculated with the formula $\mathrm{cM}=(\mathrm{TT}+6 \mathrm{NPD})$ 100/total. Dyad classes were scored as described by Rockmill and Roeder (1990). (TT) Tetratypes; (NPD) nonparental ditypes; (cM) centimorgans.

\section{MEK1 acts in the same pathway as RED1 and HOP1}

Although several mutations in yeast affect meiotic exchange, most of these completely eliminate meiotic recombination. There are three meiotic mutants that display intermediate levels of meiotic recombination: mer1 (Engebrecht and Roeder 1989), red1 (Rockmill and Roeder 1990), and hop1 (Hollingsworth and Byers 1989). Epistasis tests were carried out with these mutants.

A mek1 mer1 double mutant was constructed (BR2722), and meiotic prototroph frequencies for two loci were compared with the frequencies from each mutant alone and from the isogenic wild type. The results in Table 1 reveal that the double mutant fails to undergo any detectable meiotic recombination. Thus, mek 1 and mer1 define separate genetic pathways.

A mek1 red1 double mutant was constructed (BR2725), and recombination was measured and compared to isogenic controls (Table 1). The double mutant displays levels of recombination similar to the single mutants, implying that $M E K 1$ and RED1 act in the same genetic pathway. A previous study placed RED1 and HOP1 in the same epistasis group (Rockmill and Roeder 1990); thus, RED1, HOP1, and MEK1 must act in the same pathway. Because the mek1 red1 double mutant displays the levels of $\operatorname{Trp}^{+}$recombinants characteristic of mek1, but not red1, we tentatively place $M E K 1$ before RED1 in this pathway.

\section{The MEK1 gene is expressed only during meiosis}

The transposon used to mutagenize $M E K 1$ contains the Escherichia coli lacZ gene at one end of the element.

Table 3. Ectopic recombination in the mekl mutant

\begin{tabular}{llccc}
\hline Strain & $\begin{array}{l}\text { Relevant } \\
\text { genotype }\end{array}$ & $\begin{array}{l}\text { Mitotic } \\
\mathrm{Ura}^{+} \\
\left(\times 10^{-6}\right)\end{array}$ & $\begin{array}{l}\text { Meiotic } \\
\text { Ura }^{+} \\
\left(\times 10^{-6}\right)\end{array}$ & $\begin{array}{l}\text { Percent of } \\
\text { wild type }\end{array}$ \\
\hline BR2743 & MEK1 & 3.5 & 43 & 100 \\
BR2744 & mek1::LYS2 & 5 & 18 & 42 \\
\hline
\end{tabular}

Meiotic frequencies and percent of wild type were determined as described in Table 1. Each mitotic frequency represents the median frequency from five independent cultures. At $t$-test indicates that the meiotic frequency for wild type is significantly different from that of the mutant $(P<0.01)$.
Insertion of the transposon in the correct orientation and proper reading frame results in a mek $1:$ lac $Z$ fusion gene in which $\beta$-galactosidase production is controlled by $M E K 1$ transcription signals (Fig. 1). A fusion gene generated in this way was used to monitor MEK1 expression throughout meiosis. There was no detectable expression in vegetative cells $(0 \mathrm{hr})$. $\beta$-Galactosidase activity was maximally induced $7.5 \mathrm{hr}$ into meiosis (Fig. 4). At this time, the majority of cells are in late prophase I prior to meiosis I chromosome segregation. The kinetics of $M E K 1$ expression is similar to that of another meiosisspecific gene, RED1 (Thompson and Roeder 1989) (Fig. 4).

To determine whether expression of the MEK1 gene is regulated, a Northern blot of RNA derived from vegetative and meiotic cells was probed with $M E K 1$ sequences (Fig. 5). MEK1 RNA was observed only in meiotic cells. Two transcripts, 1.65 and $3.9 \mathrm{~kb}$ in size, were observed. The smaller transcript is $\sim 150$ nucleotides larger than the $M E K 1$ open reading frame (ORF). Because eukaryotic transcripts start translation at the first ATG codon, the larger RNA, if a functional $M E K 1$ transcript, is probably extended at the $3^{\prime}$ end. The MEK1 ORF is $1.5 \mathrm{~kb}$, and a subclone ending $0.5 \mathrm{~kb}$ from the $3^{\prime}$ end of the ORF is functional, suggesting that the smaller transcript is sufficient for MEK1 function. It is a formal possibility that one of the two transcripts represents another meiosisspecific gene, located upstream of $M E K 1$, whose $3^{\prime}$ end overlaps with the sequences used as probe.

\section{MEKl encodes a putative protein kinase}

Approximately $2 \mathrm{~kb}$ of the DNA corresponding to the $M E K 1$-complementing region was sequenced. An ORF of $1491 \mathrm{bp}$ corresponding to a predicted protein of 497 amino acids was identified. Located 125 bp upstream from the ATG initiation codon is a URS1 sequence (TCGGCGGCTA), which matches the consensus sequence exactly (Luche et al. 1990). A similar sequence is found upstream from several meiotically expressed genes (Buckingham et al. 1990).

Significant homology was observed between the predicted MEK1 protein and many serine-threonine protein kinases (Pearson and Lipman 1988; Hanks and Quinn 1991). Protein kinases have 12 characteristic domains, and within these domains are 15 invariant or nearly in- 


\section{Rockmill and Roeder}
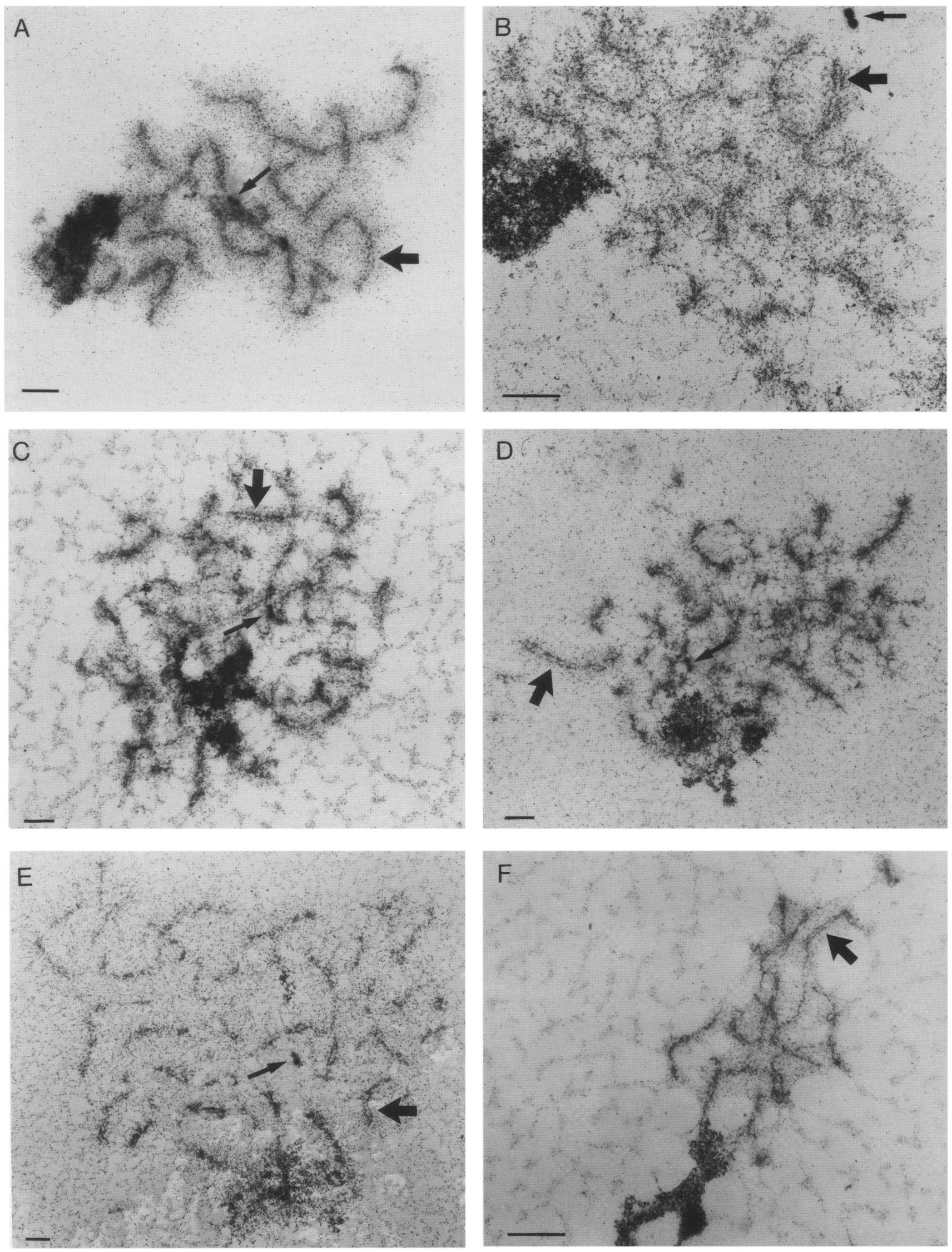

Figure 2. (See facing page for legend.) 

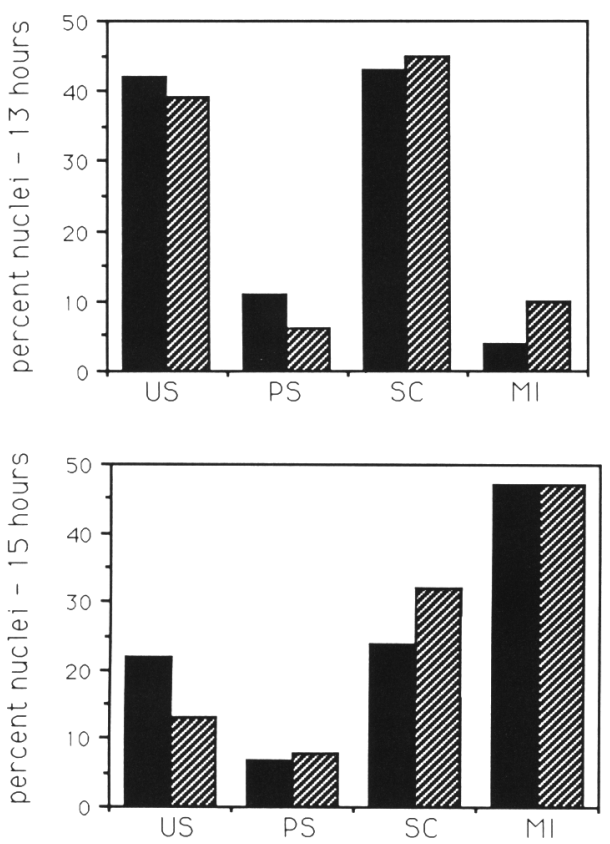

Figure 3. Distribution of meiotic cells in nuclear spreads. Solid bars represent wild-type nuclei (BR2625); hatched bars represent mek1::LYS2 nuclei (BR2626). The categories of nuclei include US (unstructured), PS (partial structure), SC, and MI (meiosis I). In the first three categories, the spindle pole bodies are duplicated but not separated. In MI nuclei, the spindle pole bodies have separated and SC is not apparent. The unstructured nuclei (US) are uniformly stained and lack SC-like structures; the partial structure (PS) category contains lightly stained, short axial elements, but no obvious $\mathrm{SC}_{\text {; }}$ the $\mathrm{SC}$ category contains either full-length (wild type) or short stretches (mutant) of SC. At least 100 nuclei were scored at each time point.

variant residues (Hanks and Quinn 1991). The MEK1 protein sequence contains all of these conserved amino acids with the appropriate spacing (Fig. 6). Comparison of subdomains VI and VIII, indicators of substrate specificity, suggests that $M E K 1$ is a serine-threonine protein kinase. The sequences related most closely to the MEK 1 protein are the calcium/calmodulin-dependent protein kinases; MEK1 displays $25 \%$ identity to CMK2 over 286 amino acids and $34 \%$ identity to CMK1 over 177 amino acids (Pausch et al. 1991). No significant homology was found outside of the protein kinase catalytic domain.

The original UV-induced mutation mek 1-1 was cloned by gap repair. Sequencing of this allele revealed two amino acid changes (Met-17 to Thr and Leu-451 to Ser). To determine which of these changes represents the mek1-1 mutation, the wild-type MEK1 gene from the

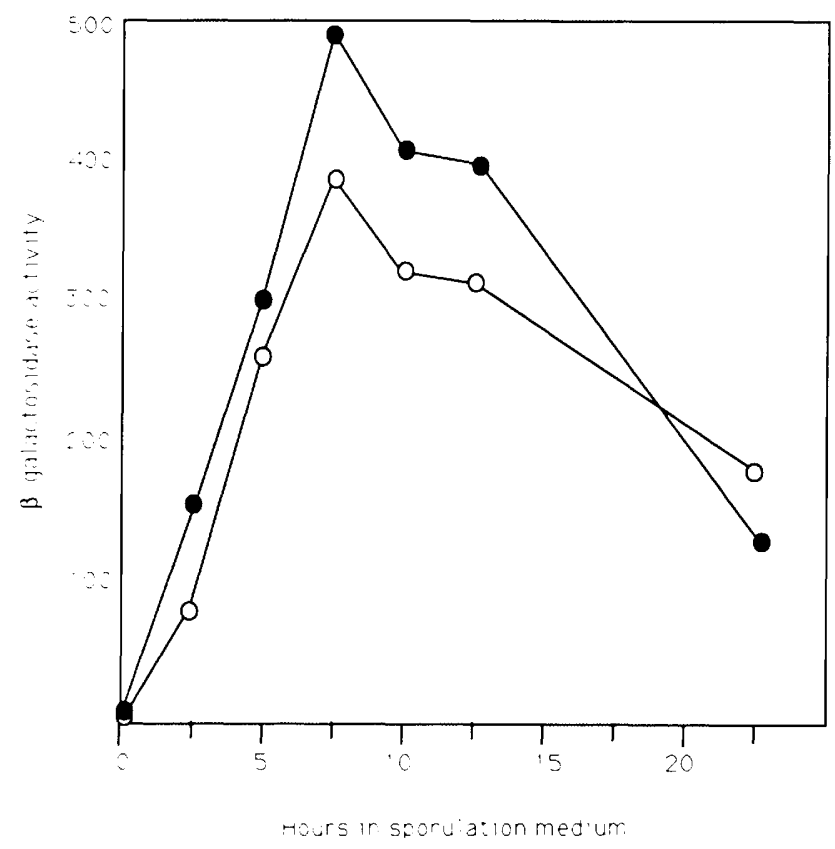

Figure 4. Expression of $\operatorname{mek} 1:: \operatorname{lac} Z$ and $\operatorname{red} 1:: \operatorname{lac} Z$ fusion genes throughout meiosis. $(0$ and $\bigcirc \beta$-Galactosidase units (nmoles of $O$-nitrophenyl- $\beta$-D-galactopyranoside (ONPG) cleaved $/ \mathrm{min} / \mathrm{mg}$ protein) in extracts derived from strains carrying mek 1::lacZ (BR2741) and red 1::lacZ (BR2740) fusion genes, respectively. Each point represents the average of the values obtained with two independent transformants. Binucleate cells, which have completed meiosis I, reach maximal abundance at $10 \mathrm{hr}$; tetranucleate cells, which have completed meiosis II, start to accumulate at $10 \mathrm{hr}$ (Thompson and Roeder 1989).

strain in which the mek 1-1 mutation was isolated was cloned and sequenced. This wild-type allele contains Thr-17 and Leu-451; thus, Thr-17 does not alter the activity of the $M E K 1$ gene, and the mek1-1 mutation changes Leu-451 to Ser. Leu-451 is located two amino acids upstream from the last conserved amino acid of the catalytic domain (Arg-453), raising the possibility that the mek1-1 mutation destroys kinase activity. Sequences flanking several of the transposon insertions that confer a $\mathrm{Mek}^{-}$phenotype were determined; these transposons were located either within the ORF or just upstream.

\section{Discussion}

We have identified a new yeast gene, $M E K 1$ (meiotic kinasel, whose product plays a role in meiotic chromosome segregation. mek1 null mutants display reduced

Figure 2. Electron micrographs of meiotic nuclear spreads. (A) Typical pachytene nucleus from a wild-type diploid, BR2625, in which chromosomes are synapsed end to end. $(B)$ Nucleus from the mek1-1 diploid BR1826-3Bm4, containing numerous stretches of SC, shorter in length than wild-type SCs. $|C-E|$ Nuclei from a mek $1:$ LYS2 diploid, BR2626. $(F)$ Nucleus from a haploid strain (T2) disomic for chromosome III, displaying regions of SC and of unsynapsed axial elements. Darkly staining bodies are the nucleoli; thin arrows indicate duplicated but unseparated spindle pole bodies. Thick arrows indicate regions of SC in which the two lateral elements are particularly distinct. Bar, $1 \mu \mathrm{m}$. 


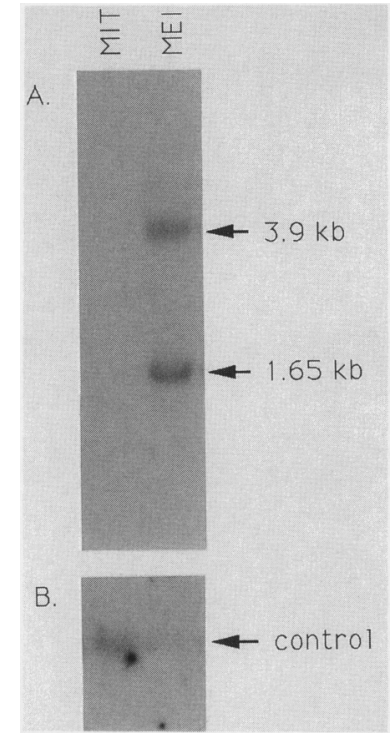

Figure 5. Transcriptional analysis of the $M E K 1$ gene in meiotic cells. RNA from wild-type vegetative (MIT) and meiotic cells (MEI) was probed with $M E K 1|A|$ and actin $(B)$ DNA. Markers used to calculate transcript sizes were the rRNAs $(3.3$ and 1.7 $\mathrm{kb})$ and the $R A D 50$ transcript $(4.2 \mathrm{~kb})$. The actin control reveals that more vegetative RNA than meiotic RNA was loaded on the gel. Previous studies have shown that the actin gene is constitutively expressed in mitosis and meiosis (Percival-Smith and Segall 1984).

levels of meiotic recombination and aberrant chromosome synapsis. The $M E K 1$ gene product is a putative protein kinase synthesized only in meiotic cells.

Meiotic genes in yeast have been divided into three classes (early, middle, and late) on the basis of the timing of transcription in meiosis (Percival-Smith and Segall 1984). Several genes whose products function in synapsis, recombination, and meiosis I chromosome disjunction display an early pattern of expression (SPO11, Atcheson et al. 1987; SPO13, Wang et al. 1987; RED1, Thompson and Roeder 1989; MER1, Engebrecht and Roeder 1990; HOP1, Hollingsworth et al. 1990; MEI4, T.M. Menees, P. Ross-Macdonald, and G.S. Roeder, in prep). The expression of a mek $1:: 1 a c Z$ fusion protein parallels the activity of a red1::lacZ fusion gene, suggesting that $M E K 1$ belongs to the early class of genes.

The predicted amino acid sequence of the MEK1 protein shows a strong homology to protein kinases, with all of the conserved amino acids present. MEK1 is most similar to the yeast calcium/calmodulin-dependent protein kinases (Pausch et al. 1991) in the catalytic domain, but homology does not extend to the calmodulin-binding domain. Analysis of the amino acid sequence suggests that $M E K 1$ encodes a serine-threonine protein kinase.

In $S$. cerevisiae, several protein kinases that function in the initiation of meiosis have been identified. A multisubunit cAMP-dependent kinase, the product of the $B C Y 1, T P K 1, T P K 2$, and TPK3 genes, monitors the levels of cAMP in response to nutrient limitation (Toda et al. 1987a,b; Yamano et al. 1987). MCK1 encodes a protein kinase with at least two known functions: It is required to ensure the fidelity of mitotic chromosome segregation (Shero and Heiter 1991) and to activate transcription of the IME1 gene (Neigeborn and Mitchell 1991). IME1 acts to positively control meiosis-specific transcription of the IME2 gene (Smith et al. 1990). The IME2 gene, which encodes a protein kinase (Yoshida et al. 1990), functions in the activation of other meiosis-specific genes or gene products (Smith and Mitchell 1989). Both the timing of expression of $M E K 1$ and the phenotype of the mutant suggest that the $M E K 1$ gene product is more likely to be involved in recombination and/or synapsis than in the regulation of gene expression.

Mutants at the RED1 and HOP1 loci display levels of recombination similar to the mek1 mutant, but their spore viability is much lower $(\sim 1 \%)$. One explanation for this discrepancy is that the crossovers that occur in mek 1 strains may be more efficient in ensuring meiosis I disjunction. Chiasmata, the physical manifestations of genetic crossovers, serve to orient the bivalents at metaphase I. Although necessary, genetic crossovers are not sufficient for proper chromosome segregation. In the desynaptic mutant of maize, the SC dissassembles prematurely and recombinant chromosomes undergo nondisjunction at meiosis I (Maguire 1978a). In red1 and mer1 strains, which do not make SC, recombinant homologs frequently nondisjoin (Engebrecht et al. 1990; Rockmill and Roeder 1990). Studies in maize indicate that synapsis is necessary to establish the sister chromatid cohesiveness that is essential for chiasma maintenance (Maguire 1990). Consistent with this hypothesis are studies of mer1 strains overexpressing the MER2 gene; such strains display $10 \%$ of wild-type levels of meiotic crossing-over but do make SC (Engebrecht et al. 1990). In these strains, recombinant chromosomes almost always segregate to opposite poles at meiosis I. Thus, the higher viability of mek1 mutants compared with red1 or hop 1 mutants may be attributable to the presence of SC.

Two lines of evidence suggest that the RED1 and HOP1 gene products are more directly involved in synapsis than in recombination. First, the HOPl protein has been localized to meiotic chromosomes (Hollingsworth et al. 1990). Second, studies of the red1 mutant reveal position effects on recombination, suggesting that the $R E D 1$ gene product does not participate directly in exchange (Rockmill and Roeder 1990). The MEK1 gene is in the same epistasis group as HOP1 and RED1, implying that mutations at all three loci disrupt (perhaps indirectly) the same aspect of recombination. However, the mek1 mutant, which has a recombination phenotype similar to the red1 and hop1 mutants, has significant amounts of SC, whereas red1 and hop1 mutants fail to make SC. These observations could be explained if the $\mathrm{SC}$ formed in mek1 strains is nonfunctional with respect to its role in recombination.

Speculations on the role of the $M E K 1$ kinase and the nature of the SC defect hinge on a determination of whether SC formation in mek1 strains takes place between homologous or nonhomologous chromosome seg- 


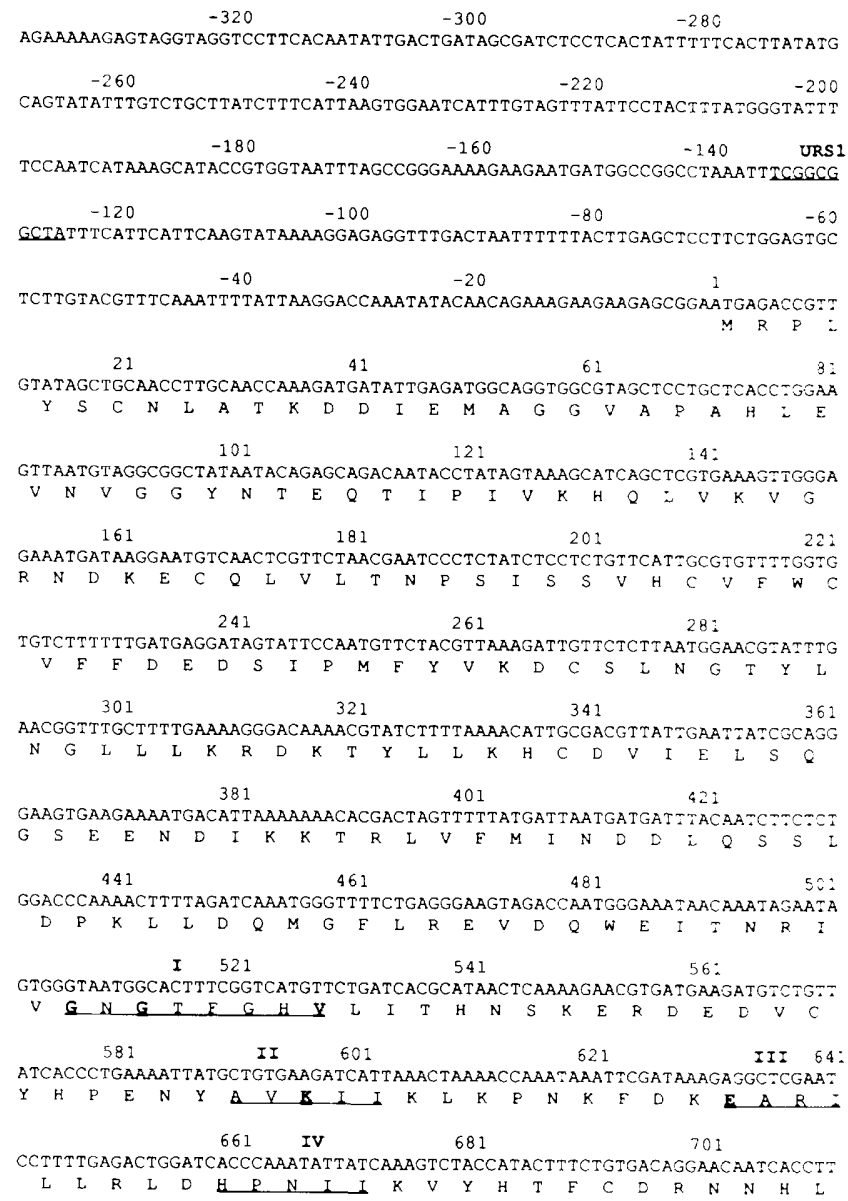

Figure 6. The DNA and predicted amino acid sequences of MEK1. The 12 protein kinase catalytic domains (Hanks and Quinn 1991) are underlined and numbered, and amino acids corresponding to the conserved amino acids of protein kinase domains are indicated in boldface type. The nucleotide sequence corresponding to the URS1 sequence is underlined. Leu-471 (at nucleotide 1353), which is changed to Ser in the mek1-1 mutant, is italicized. This sequence has been given access code X61208 by EMBL.

ments. Let us first assume that the chromosomes in mek1 strains are homologously synapsed.

In the mek1 mutant, the stretches of SC that are formed are shorter than wild-type SCs and unsynapsed axial elements are not usually apparent. In contrast, in some mutants, axial elements are full length and well defined even though synapsis is defective (rad50S, Alani et al. 1990; mer1, Engebrecht and Roeder 1990; rec102, Bhargava et al. 1991; mei4, T.M. Menees, P. Ross-Macdonald, and G.S. Roeder, in prep.). It is possible that the $M E K 1$ kinase phosphorylates a protein component of axial (and therefore lateral) elements and that the discontinuities in the $\mathrm{SC}$ are a consequence of interruptions in axial elements. The SC that does form in mek1 strains may be aberrant in structure and function (although apparently normal morphologically). One or more components of the SC may be underphosphorylated; these improperly modified proteins may be unable to associate stably with other components of the complex and/or to effect SC function(s). An alteration in SC structure could result in a defect in recombination. A defect in SC func- tion would also be consistent with the observed reduction in ectopic recombination if the SC is involved in ectopic events, as suggested by Carpenter (1987).

Another explanation for the defect in SC function is that synapsis is occurring between nonhomologous chromosome segments. During meiosis in haploid plants and yeast, there is extensive SC formation (Loidl et al. 1991; this paper|. This is probably a default mechanism used when a homologous pairing partner cannot be found. Diploids also partake in nonhomologous synapsis, for example, when an inversion is heterozygous. In this case, a homologously paired inversion loop is made first, and synaptic adjustment then results in a rod-shaped chromosome with the inverted segment paired nonhomologously (Moses et al. 1982).

How can the SC in mek1 strains provide functional chiasmata if (most of) the chromosomes are paired nonhomologously? Recombination events in hop1 and red1 mutants occur outside the context of an SC. Epistasis analysis reveals that the same subset of recombinants are formed in mek 1 mutants. As indicated above, studies 
in maize indicate that synapsis is required to establish sister chromatid cohesiveness and, therefore, to provide chiasma function. Maguire's work also demonstrates that SC formation between nonhomologous chromosome segments is effective in establishing cohesiveness between sister chromatids (Maguire 1979, 1982). Thus, it is possible that a crossover between homologous chromosomes, accompanied by nonhomologous synapsis distal to the crossover site, would establish a functional connection (chiasma) between the two recombinant homologs. Alternatively, it is possible that the chromosomes that recombine in mek1 strains do pair homologously. In this case, mek1 nuclei would contain a mixture of homologously and nonhomologously synapsed chromosomes.

Chromosome homology searches are probably mediated by DNA interactions (Smithies and Powers 1986; Carpenter 1987). Multiple attempts at searching (i.e., sequence comparisons) probably take place before homology is found, at which point chromosome synapsis may be initiated. mek1 mutants may be defective in discriminating good from poor (or long from short) homology, so that even nonhomologous interactions trigger synapsis, thus removing the chromosomes from the pool of available sequences. This would result in reduced levels of both allelic and ectopic recombination. If synapsis in mek1 strains is nonhomologous, then the MEK l protein may play a role in the search for (or recognition of) chromosomal homology. Perhaps the signal to start the homology search involves the activation of a protein or protein complex by phosphorylation. If an early step in recombination is required for synapsis (Smithies and Powers 1986; Carpenter 1987; Alani et al. 1990; Roeder 1990 ), then the MEK1 kinase may be required for the activation of a recombination enzyme $\mid \mathbf{s}\}$. Nonhomologous synapsis would occur by default when homolog recognition fails.

In future studies of $M E K 1$ it will be important to determine whether the chromosomes are homologously or nonhomologously paired. In addition, the isolation of second-site supressors may help to elucidate the role of $M E K 1$ in meiosis.

\section{Materials and methods}

Strains and media

Yeast strains are listed in Table 4. Media were prepared according to Sherman et al. (1986). Liquid sporulation medium is $2 \%$ potassium acetate.

\section{Isolation of mek1-1}

The mek1-1 mutant was isolated in a screen for meiotic-lethal mutants as described previously (Rockmill and Roeder 1988). Briefly, spores from a homothallic diploid were mutagenized with UV at a dose sufficient to kill $50 \%$ of the cells. The haploid spores grew up into diploid colonies as a result of $\mathrm{HO}$-induced mating-type switching followed by self-mating (Strathern and Herskowitz 1979|. These diploids, homozygous for any induced mutations, were sporulated and exposed briefly to ether vapors to kill any unsporulated diploid cells (Rockmill et al. 1991). For those colonies that failed to grow after the exposure to ether, cells from the sporulation plate were examined in the light microscope to assess spore formation. Sporulation-competent, meiotic-lethal mutants were chosen for further study.

\section{Genetic manipulations}

Yeast transformations were carried out by the lithium acetate procedure (Ito et al. 1983), and substitutive transformations were verified by Southern blot analysis (Sambrook et al. 1989).

The original mek1-1 isolate, BR1826-3Bm4, is a homothallic diploid. To generate stable haploid segregants, the spores of BR1826-3Bm4 were mated to a haploid (BR1373-6DSF) and zygotes were selected. Cells from several zygotes were tested for the ability to form viable spores by ether tests. Most zygote colonies produced inviable spores because the spores derived from a mek1-1 diploid are often aneuploid. Tetrads from an apparent diploid were dissected, and cells from mating-competent spore colonies were tested for the segregation of the meiotic-lethal phenotype by mating to other segregants of the same cross and testing the resulting diploids for viable spore production. Several subsequent crosses were carried out to separate the mek1-1 mutation from any other mutations that might have been induced during UV mutagenesis and to introduce genetic markers for recombination assays. Meiotic recombination frequencies (intergenic, intragenic, and ectopic) were determined as described by Rockmill and Roeder (1990).

\section{Cloning of MEKI}

A homozygous mek1-1 leu2 diploid was transformed with a yeast genomic library in a centromere-containing vector marked with LEU2. This library, obtained from F. Spencer and P. Heiter (unpubl.), consists of yeast genomic DNA partially digested with Sau3A and inserted at the BamHI site of vector pBS32, a YCp50 derivative in which URA3 is replaced by $L E U 2$. Transformants were sporulated and screened for the ability to grow after ether exposure. Plasmids were isolated from yeast by electroporation of $E$. coli (Sambrook et al. 1989) with yeast miniprep DNA (Sherman et al. 1986).

\section{Plasmids}

$\mathrm{pB} 107$ is the original isolate of the MEK1 gene from a yeast genomic library; pB107 contains $\sim 7.5 \mathrm{~kb}$ of insert DNA. pB131 is a subclone of the 5-kb EcoRI fragment of $\mathrm{pB107}$ (Fig. 1) into the ECORI site of pUN70, a URA3- and CEN-containing plasmid (Elledge and Davis 1988). In pB121, most of the MEK1-coding region is replaced by $L Y S 2$. To construct $\mathrm{pB} 12 \mathrm{l}$, the $3-\mathrm{kb} E$ CoRIPvull fragment of $\mathrm{pB} 107$ was first inserted between the EcoRI and $E c O R V$ sites of pBR322 to generate pB124. Then, the $5-\mathrm{kb}$ XbaI-Pvull fragment of pDP6 (Fleig et al. 1986) containing the LYS2 gene was inserted between the $\mathrm{XbaI}$ and $\mathrm{HpaI}$ sites of $\mathrm{pB} 124$ to generate $\mathrm{pB} 121$. This plasmid was digested with EcoRI and HindIII prior to transformation into yeast to replace the MEK1 gene. This allele, mek $1:: L Y S 2$, was used to map the $M E K 1$ gene.

pB126 is the same as pB107, except the MEK1 gene is replaced by the mek1-1 allele. pB146 is the same as pBl07 except it carries the wild-type $M E K 1$ gene from the strain in which the mek1-1 allele was originally isolated. $\mathrm{pB} 126$ and $\mathrm{pB} 146$ were made by gap repair. $\mathrm{pB} 107$ was cut with $\mathrm{XbaI}$ and religated to generate plasmid $\mathrm{pB120}$; this plasmid was then cut with $X b a \mathrm{I}$ and transformed into mek1-1 or MEK1 yeast. Plasmids were isolated from the yeast transformants by electroporation of $E$. 
Table 4. Yeast strains

\begin{tabular}{|c|c|}
\hline Strain & Genotype \\
\hline BR1373-6DSF & MATa his4-280 leu2-27 trp1-1 spo13::ura3-1 arg4-8 thr1-1 ura3-1 lys2-98 cyh10 ade2-1 \\
\hline $\mathrm{BR} 1826-3 \mathrm{Bm} 4$ & 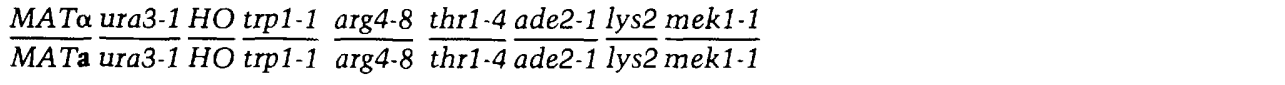 \\
\hline BR2171-7B & $\frac{\text { MAT } \alpha \text { leu2-27 }}{\text { MATa leu2-27 }} \frac{\text { his4-280 }}{\text { his4-280 }} \frac{\text { ura3-1 }}{\text { ura3-1 }} \frac{\text { HO }}{\text { HO }} \frac{\operatorname{trp1-1}}{\operatorname{trp} 1-1} \frac{\text { ade2-1 }}{\text { ade2-1 }}$ \\
\hline BR2481 & 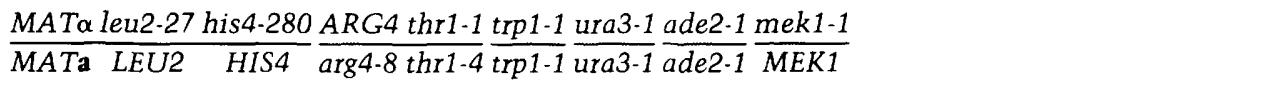 \\
\hline BR2500 & BR2625 but $\frac{\text { red1::ADE2 }}{\text { red1::ADE2 }}$ \\
\hline BR2625 & $\frac{\text { MAT } \alpha \text { leu2-27 his4-280 }}{\text { MATa leu2-3, } 112 \text { his4-260 ura3-1 }} \frac{\text { urp1-1 }}{\operatorname{trp1-289}} \frac{\text { spo13::ura3-1 ARG4 thr1-4 }}{\text { spo13::ura3-1 arg4-8 thr1-1 }} \frac{\text { cyh10 }}{\text { CYH10 }} \frac{\text { ade2-1 }}{\text { ade2-1 }} \frac{\text { lys2-98 }}{\text { lys2-98 }}$ \\
\hline BR2626 & BR2625 but $\frac{\text { mek } 1:: L Y S 2}{\text { mek } 1:: L Y S 2}$ \\
\hline BR2702 & $\frac{\text { MATa leu2-3, } 112 \text { his4-260 }}{\text { MATa leu2-27 his4-280 }} \frac{\text { ura3-1 }}{\text { ura3-1 }} \frac{\operatorname{trp1-1}}{\text { trp1-1 }} \frac{\text { spo13::ura3-1 arg4-8 thr1-4 }}{\text { spo13::ura3-1 arg4-8 thr1-4 }} \frac{\text { cyh10 }}{\text { CYH10 }} \frac{\text { ade2-1 }}{\text { ade2-1 }} \frac{\text { lys2-98 }}{\text { lys2-98 }} \frac{\text { mek 1-1 }}{\text { mek1-1 }}$ \\
\hline BR2722 & BR2702 but $\frac{\operatorname{mer} 1:: L Y S 2}{\operatorname{mer} 1:: L Y S 2}$ \\
\hline BR2723 & $\frac{\text { MATa leu2-3, } 112 \text { his4-260 }}{\text { MATa leu2-27 HIS4 }} \frac{\text { ura3-1 }}{\text { ura3-1 }} \frac{\operatorname{trp1-1}}{\text { trp1-289 }} \frac{\text { spo13::ura3-1 ARG4 thr1-4 }}{\text { spo13::ura3-1 arg4-8 THR1 }} \frac{\text { cyh10 }}{\text { CYH10 }} \frac{\operatorname{trp} 1-1}{\operatorname{trp}-289} \frac{\text { ade2-1 }}{\text { ade2-1 }}$ \\
\hline BR2724 & BR2723 but $\frac{\text { mek } 1:: L Y S 2}{\text { mek } 1:: L Y S 2}$ \\
\hline BR2725 & BR2626 but $\frac{\text { red } 1:: L E U 2}{\text { red } 1:: L E U 2}$ \\
\hline BR2736 & 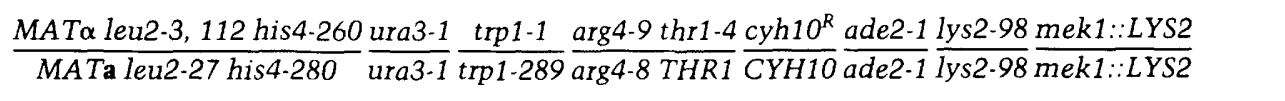 \\
\hline BR2738 & BR2702 but $p B 131$ (MEK1) \\
\hline BR2739 & BR2722 but $p B 131$ (MEK1) \\
\hline NKY611 & 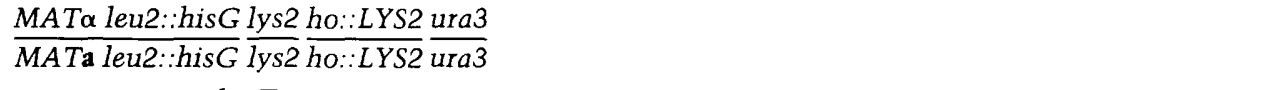 \\
\hline BR2740 & NKY611 but $\frac{\text { red1::Tn69 }}{R E D 1}$ \\
\hline BR2741 & NKY611 but $\frac{m e k 1:: \operatorname{Tn} 118}{M E K 1}$ \\
\hline \multirow[t]{2}{*}{ BR 2743} & 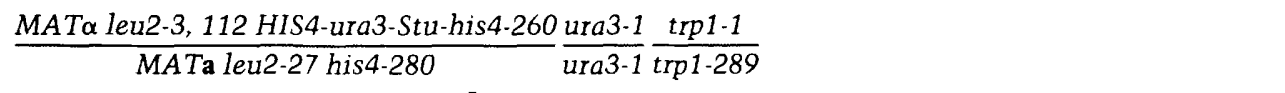 \\
\hline & $\frac{\text { spo13::ura3-1 ARG4 thr1-4 }}{\text { spo13::ura3-1 4arg4-8 thr1-1 }} \frac{\text { cyh10R }}{\text { CYH10 }} \frac{\text { ade2-1 }}{\text { ade2-1 } 1 \text { lys2-98 }} \frac{\text { lys2-98 }}{4}$ \\
\hline BR2744 & BR2743 but $\frac{\text { mek } 1:: L Y S 2}{\text { mek } 1:: L Y S 2}$ \\
\hline $\mathrm{T} 2$ & $\frac{\text { MAT } \alpha \text { his4-260 leu2-3, } 112}{\text { MATa his4-280 leu2-27 }}$ spo13::URA3 arg4-8 thr1-1 ade2-1 lys2-98 \\
\hline
\end{tabular}

NKY611 was obtained form N. Kleckner (Harvard University). For the construction of a strain similar to BR2743 (used in the ectopic recombination assay), see Rockmill and Roeder (1990).

coli (Sambrook et al. 1989) with yeast DNA minipreps (Sherman et al. 1986) and analyzed by restriction digests.

pB122 and $\mathrm{pB} 123$ were used for DNA sequence analysis. $\mathrm{pB} 122$ contains the $1.2 \mathrm{~kb}$ XbaI-HindIII fragment of $\mathrm{pB} 107$ in the same sites of SK + (Stratagene). pB123 contains the $0.9-\mathrm{kb}$ HindIII fragment of pB107 in the HindIII site of SK + .

$\mathrm{pB} 110$ contains the same $5-\mathrm{kb}$ fragment as $\mathrm{pB} 107$ in the EcoRI site of pHSS6 (Seifert et al. 1986), a vector used for transposon mutagenesis. $\mathrm{pB} 118$ is an insertion mutant derived from $\mathrm{pB} 110$ in which the $l a c Z$ gene in the transposon is fused in-frame to the $M E K 1$ gene. pB69 contains a transposon insertion in the $R E D 1$ gene in which the lacZ gene is fused in-frame to RED1 (Rockmill and Roeder 1988). pB72 contains a deletion-disruption allele of the RED1 gene marked by the $L E U 2$ gene (Rock- 
mill and Roeder 1990). pME6 contains a deletion-disruption of the MER1 gene marked with the LYS2 gene (Engebrecht and Roeder 1989). p(SPO13)16 contains a deletion-disruption of the SPO13 gene marked with URA3 (Wang et al. 1987). pR1345 contains a 201-bp AluI fragment of the actin gene in SK + (Engebrecht et al. 1991).

\section{Cytology}

Fresh overnight cultures grown in YEPD supplemented with adenine were diluted two- to threefold with fresh medium and grown for 5-8 hr. These cultures were induced to undergo meiosis by resuspending pelleted cells in seven times as much sporulation medium ( $2 \%$ potassium acetate). Meiotic chromosomes were spread for electron microscopy according to Dresser and Giroux (1988) as modified by Engebrecht and Roeder (1990).

\section{Transposon mutagenesis}

pB110 (see above) was used in the transposon mutagenesis protocol described by Seifert et al. (1986). Plasmids containing the transposon insertions to be tested were cut with NotI and transformed into the homothallic diploid BR2171-7B. The heterozygous transformants were sporulated, and tetrads were dissected. The spore colonies are diploids homozygous for either the disruption $\left(\mathrm{Leu}^{+}\right)$or wild-type sequence $\left(\mathrm{Leu}^{-}\right)$. Spore viability was assessed by replica-plating to sporulation medium followed by ether tests. For those transformants in which leucine prototrophy and spore lethality cosegregated, the spore inviability of the homozygous mutants was confirmed by tetrad dissection. The original transformants, heterozygous for the insertions, were also tested for the production of $\beta$-galactosidase (Strich et al. 1989). Only one insertion, derived from pB118, showed meiosis-specific color development.

\section{Sequencing strategy}

The sequencing of both strands of $1911 \mathrm{bp}$ of the $M E K 1$ region was obtained by the dideoxy method (Sambrook et al. 1989) using $\mathrm{T} 7$ polymerase (Pharmacia) on double-stranded template. Most of the sequence information came from a series of deletion derivatives of $\mathrm{pB} 122$ and $\mathrm{pB} 123$ generated using the Erase-a-base system (Promega). Additional sequence was obtained by sequencing plasmids carrying transposon insertions using a primer complementary to $l a c Z$. The remainder of the sequence was obtained using synthetic oligonucleotide primers. The gaprepaired plasmids, $\mathrm{pB} 126$ and $\mathrm{pB} 146$, were sequenced using oligonucleotide primers that span the $M E K 1$ coding region.

\section{$\beta$-Galactosidase assays}

Strains BR2740 and BR2741, heterozygous for transposon insertions of $R E D 1$ and $M E K 1$, respectively, were used to study the expression of these genes. The mek $1: 1 a c Z$ and red $1: 1 a c Z$ fusion genes were introduced into the SK1 derivative NKY611, which sporulates more rapidly than the other strains used in this study (Fast 1973). Extracts were prepared from meiotic cells, and $\beta$-galactosidase assays were performed according to Coney and Roeder (1988).

\section{RNA analysis}

RNA was prepared according to Schmitt et al. (1990) from cells harvested prior to sporulation and from cells induced in sporulation medium for $15 \mathrm{hr}$. Northern blot analysis was carried out as described by Sambrook et al. (1989). DNA probes were pre- pared from the XbaI-HpaI fragment from $\mathrm{pB} 131$ (MEK1) and from the 201-bp AluI fragment of actin (pR1345).

\section{Acknowledgments}

We thank Petra Ross-Macdonald for providing the RNA blot, and JoAnne Engebrecht, Petra Ross-Macdonald, and Krishnan Nandabalan for critically reading the manuscript. This work was supported by American Cancer Society grant MV-405A.

The publication costs of this article were defrayed in part by payment of page charges. This article must therefore be hereby marked "advertisement" in accordance with 18 USC section 1734 solely to indicate this fact.

\section{References}

Alani, E., R. Padmore, and N. Kleckner. 1990. Analysis of wildtype and rad50 mutants of yeast suggests an intimate relationship between meiotic chromosome synapsis and recombination. Cell 61: 419-436.

Atcheson, C.L., B. DiDomenico, S. Frackman, and R.E. Esposito. 1987. Isolation, DNA sequence, and regulation of a meiosis-specific eukaryotic recombination gene. Proc. Natl. Acad. Sci. 84: 8035-8039.

Baker, B.S., A.T.C. Carpenter, M.S. Esposito, R.E. Esposito, and L. Sandler. 1976. The genetic control of meiosis. Annu. Rev. Genet. 10: 53-134.

Bhargava, J., J. Engebrecht, and G.S. Roeder. 1992. The rec102 mutant of yeast is defective in meiotic recombination and chromosome synapsis. Genetics (in press).

Buckingham, L.E., H.-T. Wang, Z.T. Elder, R.M. McCarroll, M.R. Slater, and R.E. Esposito. 1990. Nucleotide sequence and promoter analysis of SPO13, a meiosis-specific gene of Saccharomyces cerevisiae. Proc. Natl. Acad. Sci. 87: 94069410.

Carpenter, A.T.C. 1987. Gene conversion, recombination nodules, and the initiation of meiotic synapsis. BioEssays 6: 232-236.

Chu, G., D. Vollrath, and R.W. Davis. 1986. Separation of large DNA molecules by contour-clamped homogeneous electric fields. Science 234: 1582-1585.

Coney, L.R. and G.S. Roeder. 1988. Control of yeast gene expression by transposable elements: Maximum expression requires a functional Ty activator sequence and a defective Ty promoter. Mol. Cell. Biol. 8: 4009-4017.

Dresser, M.E. and C.N. Giroux. 1988. Meiotic chromosome behavior in spread preparations of yeast nuclei. I. Cell Biol. 106: $567-578$.

Egel, R. 1978. Synaptonemal complexes and crossing-over: Structural support or interference? Heredity 41: 233-237.

Elledge, S.J. and R.W. Davis. 1988. A family of versitile centromeric vectors designed for use in the sectoring-shuffle mutagenesis assay in Saccharomyces cerevisiae. Gene 70: 303312 .

Engebrecht, J. and G.S. Roeder. 1989. Yeast mer1 mutants display reduced levels of meiotic recombination. Genetics 121: 237-247.

-1990. MER1, a yeast gene required for chromosome pairing and genetic recombination, is induced in meiosis. Mol. Cell. Biol. 10: 2379-2389.

Engebrecht, J., J. Hirsch, and G.S. Roeder. 1990. Meiotic gene conversion and crossing over: Their relationship to each other and to chromosome synapsis and segregation. Cell 62: 927-937.

Engebrecht, J., K. Voelkel-Meiman, and G.S. Roeder. 1991. mei- 
osis-specific RNA splicing in yeast. Cell 66: 1257-1268.

Fast, D. 1973. Sporulation synchrony of Saccharomyces cerevisiae grown in various carbon sources. J. Bacteriol. 116: 925930.

Fleig, U.N., R.D. Pridmore, and P. Philippsen. 1986. Construction of LYS2 cartridges for use in genetic manipulation of Saccharomyces cerevisiae. Gene 46: 237-245.

Hanks, S.K. and A.M. Quinn. 1991. Protein kinase catalytic domain sequence database: Identification of conserved features of primary structure and classification of family members. Methods Enzymol. 200: 38-61.

Hawley, R.S. 1988. Exchange and chromosomal segregation in eucaryotes. In Genetic recombination (ed. R. Kucherlapati and G.R. Smith), pp. 497-527. American Society for Microbiology, Washington, D.C.

Hollingsworth, N.M. and B. Byers. 1989. HOP1: A yeast meiotic pairing gene. Genetics 121: 445-462.

Hollingsworth, N.M., L. Goetsch, and B. Byers. 1990. The HOP1 gene encodes a meiosis-specific component of yeast chromosomes. Cell 61: 73-84.

Hurst, D., S. Fogel, and R.K. Mortimer. 1972. Conversion-associated recombination in yeast. Proc. Natl. Acad. Sci. 69: 101-105.

Ito, H., Y. Fukada, K. Murata, and A. Kimura. 1983. Transformation of intact yeast cells treated with alkali cations. I. Bacteriol. 153: 163-168.

Jinks-Robertson, S. and T.D. Petes. 1985. High-frequency meiotic gene conversion between repeated genes on nonhomologous chromosomes in yeast. Proc. Natl. Acad. Sci. 82: 3350-3354.

Jones, G.H. 1987. Chiasmata. In Meiosis (ed. P.B. Moens), pp. 213-244. Academic Press, Orlando, FL.

Klapholz, S. and R.E. Esposito. 1980. Isolation of spo12-1 and spo13-1 from a natural variant of yeast that undergoes a single meiotic division. Genetics 96: 567-588.

Lichten, M., R.H. Borts, and J.E. Haber. 1987. Meiotic gene conversion and crossing over between dispersed homologous sequences occurs frequently in Saccharomyces cerevisiae. Genetics 115: 233-246.

Loidl, J., K. Nairz, and F. Klein. 1991. Meiotic chromosome synapsis in a haploid yeast. Chromosoma 100: 221-228.

Luche, R.M., R. Sumrada, and T.G. Cooper. 1990. A cis-acting element present in multiple genes serves as a repressor protein binding site for the yeast CAR1 gene. Mol. Cell. Biol. 10: 3884-3895.

Maguire, M.P. 1978a. Evidence for separate genetic control of crossing over and chiasma maintenance in maize. Chromosoma 65: 173-183.

- 1978 b. A possible role for the synaptonemal complex in chiasma maintenance. Exp. Cell Res. 112: 297-308.

- 1979. An indirect test for a role of the synaptonemal complex in the establishment of sister chromatid cohesiveness. Chromosoma 70: 313-321.

- 1982. Evidence for a role of the synaptonemal complex in provision for normal chromosome disjunction at meiosis II in maize. Chromosoma 84: 675-686.

- 1988. Crossover site determination and interference. $I$. Theor. Biol. 134: 565-570.

-1990. Sister chromatid cohesiveness: Vital function, obscure mechanism. Biochem. Cell Biol. 68: 1231-1242.

Malone, R.E. 1990. Dual regulation of meiosis in yeast. Cell 61: 375-378.

Malone, R.E. and R. Easton Esposito. 1981. Recombinationless meiosis in Saccharomyces cerevisiae. Mol. Cell. Biol. 10: 891-901.

Malone, R.E., S. Bullard, M. Hermiston, R. Rieger, M. Cool, and
A. Galbraith. 1991. Isolation of mutants defective in early steps of meiotic recombination in the yeast Saccharomyces cerevisiae. Genetics 128: 79-88.

Menees, T.M. and G.S. Roeder. 1989. MEI4, a yeast gene required for meiotic recombination. Genetics 123: 675-682.

Moses, M.J., P.A. Poorman, T.H. Roderick, and M.T. Davisson. 1982. Synaptonemal complex analysis of mouse chromosomal rearrangements IV. Synapsis and synaptic adjustment in two paracentric inversions. Chromosoma 84: 457-474.

Neigeborn, L. and A.P. Mitchell. 1991. The yeast MCK1 gene encodes a protein kinase homolog that activates early meiotic gene expression. Genes \& Dev. 5: 533-548.

Pausch, M.H., D. Kaim, R. Kunisawa, A. Admon, and J. Thorner. 1991. Multiple $\mathrm{Ca}^{2+} /$ calmodulin-dependent protein kinase genes in a unicellular eukaryote. EMBO /. 10: 1511-1522.

Pearson, W.R. and D.J. Lipman. 1988. Improved tools for biological sequence comparison. Proc. Natl. Acad. Sci. 85: 2444-2448.

Percival-Smith, A. and J. Segall. 1984. Isolation of DNA sequences preferentially expressed during sporulation in Saccharomyces cerevisiae. Mol. Cell. Biol. 4: 142-150.

Rockmill, B. and G.S. Roeder. 1988. RED1: A yeast gene required for the segregation of chromosomes during the reductional division of meiosis. Proc. Natl. Acad. Sci. 85: 60576061 .

-1990. Meiosis in asynaptic yeast. Genetics 126:563574.

Rockmill, B., E.J. Lambie, and G.S. Roeder. 1991. Spore enrichment. Methods Enzymol. 194: 146-149.

Roeder, G.S. 1990. Chromosome synapsis and genetic recombination: Their roles in meiotic chromosome segregation. Trends Genet. 6: 385-389.

Sambrook, J., E.F. Fritsch, and T. Maniatis. 1989. Molecular cloning: A laboratory manual, 2nd ed.. Cold Spring Harbor Laboratory Press, Cold Spring Harbor, New York.

Schmitt, M.E., T.A. Brown, and B.L. Trumpower. 1990. A rapid and simple method for preparation of RNA from Saccharomyces cerevisiae. Nucleic Acids Res. 18: 3091-3092.

Seifert, H.S., M. So, and F. Heffron. 1986. Shuttle mutagenesis: A method of introducing transposons into transformable organisms. In Genetic engineering: Principles and methods (ed. J.K. Setlow and A. Hollaender), pp. 123-134. Plenum Press, New York.

Sherman, F., G.R. Fink, and J.B. Hicks. 1986. Methods in yeast genetics: A laboratory manual. Cold Spring Harbor Laboratory, Cold Spring Harbor, New York.

Shero, J.H. and P. Heiter. 1991. A suppressor of a centromere DNA mutation encodes a putative protein kinase (MCK1). Genes \& Dev. 5: 549-560.

Smith, H.E. and A.P. Mitchell. 1989. A transcriptional cascade governs entry into meiosis in Saccharomyces cerevisiae. Mol. Cell. Biol. 9: 2142-2152.

Smith, H.E., S.Y.S. Su, L. Neigeborn, S.E. Driscoll, and A.P. Mitchell. 1990. Role of IME1 expression in regulation of meiosis in Saccharomyces cerevisiae. Mol. Cell Biol. 12: $6103-6113$.

Smithies, O. and P.A. Powers. 1986. Gene conversions and their relation to homologous chromosome pairing. Phil. Trans. $R$. Soc. Lond. B 312: 291-302.

Strathern, J.N. and I. Herskowitz. 1979. Asymmetry and directionality in production of new cell types during clonal growth: The switching pattern of homothallic yeast. Cell 17: $371-387$.

Strich, R., M.R. Slater, and R.E. Esposito. 1989. Identification of negative regulatory genes that govern the expression of early meiotic genes in yeast. Proc. Natl. Acad. Sci. 86: 10018- 


\section{Rockmill and Roeder}

10022.

Thompson, E.A. and G.S. Roeder. 1989. Expression and DNA sequence of $R E D 1$, a gene required for meiosis I chromosome segregation in yeast. Mol. Gen. Genet. 218: 293-301.

Toda, T., S. Cameron, P. Sass, M. Zoller, J.D. Scott, B. McMullen, M. Hurwitz, E.G. Krebs, and M. Wigler. 1987a. Cloning and characterization of $B C Y 1$, a locus encoding a regulatory subunit of the cyclic AMP-dependent protein kinase in Saccharomyces cerevisiae. Mol. Cell. Biol. 7: 277287.

Toda, T., S. Cameron, P. Sass, M. Zoller, and M. Wigler. 1987b. Three different genes in $S$. cerevisiae encode the catalytic subunits of the cAMP-dependent protein kinase. Cell 50: 277-287.

von Wettstein, D., S.W. Rasmussen, and P.B. Holm. 1984. The synaptonemal complex in genetic segregation. Annu. Rev. Genet. 18: 331-413.

Wang, H., S. Frackman, J. Kowalisyn, R.E. Esposito, and R. Elder. 1987. Developmental regulation of SPO13, a gene required for separation of homologous chromosomes at meiosis I. Mol. Cell. Biol. 7: 1425-1435.

Yamano, S., K. Tanaka, K. Matsumoto, and A. Toh-e. 1987. Mutant regulatory subunit of 3',5'-cAMP-dependent protein kinase of yeast Saccharomyces cerevisiae. Mol. Gen. Genet. 210: 413-418.

Yoshida, M., H. Kawaguchi, Y. Sakata, K. Kominami, M. Hirano, H. Shima, R. Akada, and I. Yamashita. 1990. Initiation of meiosis and sporulation in Saccharomyces cerevisiae requires a novel protein kinase homologue. Mol. Gen. Genet. 221: 176-186. 


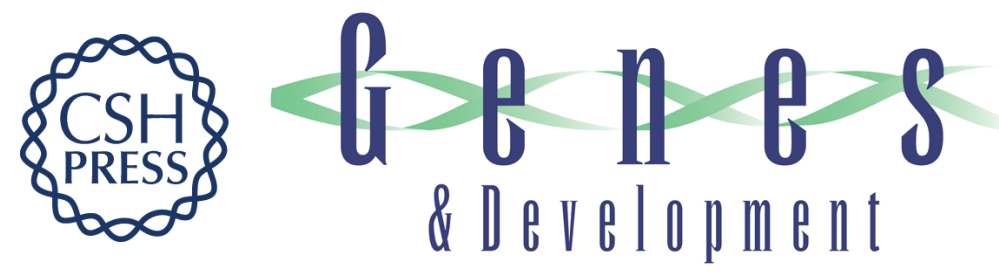

\section{A meiosis-specific protein kinase homolog required for chromosome synapsis and recombination.}

B Rockmill and G S Roeder

\section{Genes Dev. 1991, 5:}

Access the most recent version at doi:10.1101/gad.5.12b.2392

References This article cites 59 articles, 26 of which can be accessed free at:

http://genesdev.cshlp.org/content/5/12b/2392.full.html\#ref-list-1

License

Email Alerting

Service

Receive free email alerts when new articles cite this article - sign up in the box at the top right corner of the article or click here.

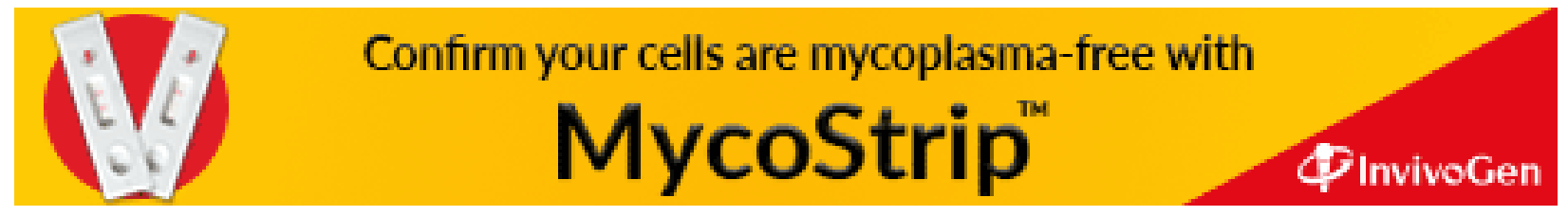

